\title{
IMPLEMENTASI SENAM PENGUIN SEBAGAI KEGIATAN OLAHRAGA RUTIN SANTRI PONPES SABILUNAJAT
}

\section{IMPLEMENTATION OF PINGUIN GYMNASTICS AS A SPORT OF SABILUNAJAT SANTRI ACTIVITIES}

\author{
${ }^{1)}$ Dadang Herdiansyah ${ }^{*},{ }^{2)}$ Noor Latifah, ${ }^{3)}$ Oswin Yohsa Ibarahim \\ ${ }^{1,2,3)}$ Fakultas Kesehatan Masyarakat, Universitas Muhammadiyah Jakarta \\ Alamat: Jl. KH. Ahmad Dahlan, Cireudeu, Ciputat \\ "Email: danksepid09@gmail.com
}

\begin{abstract}
ABSTRAK
Aktivitas fisik pada remaja, termasuk siswa, bermanfaat dalam meningkatkan status kesehatan dan meningkatkan pendapatan yang dapat mendukung produktivitas dan konsentrasi dalam pembelajaran. Selain itu, mencegah kanker kardiovaskular, diabetes, kanker usus besar dan kanker payudara dan depresi. aktivitas fisik memiliki tubuh dan tinggi yang panjang. Aktivitas fisik dapat berupa berlari, melompat dan melakukan latihan yang memiliki efek efektif pada peningkatan tulang. Anggota Pengabdian Masyarakat Ini untuk melihat dari pelaksanaan Senam Pingun pada siswa di Madrasah Sabilunnajat Ciamis Jawa Barat yang memiliki jadwal yang sangat baik untuk meningkatkan perlindungan otot. Latihan ini dilakukan ketika siswa melakukan olahraga rutin yang dilakukan oleh beberapa siswa untuk menemani mereka. Metode yang digunakan adalah menggunakan video senam penguin dengan durasi 3 menit dan diulang dua kali. Hasil yang diperoleh dari penerapan senam penguin adalah siswa baru yang disetujui yang berada dalam gerakan seperti ini yang unik dan tidak dikeluarkan. Semoga senam penguin ini bisa diterapkan oleh siswa dan pesantren.
\end{abstract}

Kata kunci: aktifitas fisik, senam penguin, santri

\begin{abstract}
Physical activity in adolescents, including students, is beneficial in improving health status and increasing income that can support productivity and concentration in learning. In addition, it prevents cardiovascular cancer, diabetes, colon cancer and breast cancer and depression. physical activity has a long body and height. Physical activity can take the form of running, jumping and doing exercises that have an effective effect on bone enhancement. Members of Community Service This is to see from the implementation of pingun gymnastics at students in the Madrasah Sabilunnajat Ciamis West Java who have an excellent schedule for improving muscle protection. This exercise is done when students do routine sports conducted by several students to accompany them. The method used is to use video penguin gymnastics with a duration of 3 minutes and repeated twice. The results obtained from the implementation of the penguin gymnastics are the new approved santri who are in movements like this that are unique and not issued. Hopefully this penguin gymnastics can be applied by students and Islamic boarding schools
\end{abstract}

Keyword : Physical Activity, Pinguin Gymnastics, Islamic Student 
AS-SYIFA: Jurnal Pengabdian dan Pemberdayaan Kesehatan Masyarakat

\section{PENDAHULUAN}

Aktivitas fisik adalah setiap gerakan tubuh yang meningkatkan pengeluaran energi dan pembakaran energi. Aktivitas fisik dikategorikan cukup apabila melakukan aktivitas fisik atau olahraga dalam sehari atau minimal 3-5 kali dalam seminggu. (Miles, 2007). Sedangkan Menurut (Kemenkes, 2015) aktivitas fisik adalah setiap gerakan tubuh yang diakibatkan kerja otot rangka dan meningkatkatn pengeluaran tenaga serta energi. Aktivitas yang diamaksud adalah aktivitas yang dilakukan di sekolah, ditempat kerja , aktivitas dalam keluarga aktivitas dalam perjalanan dan aktivitas lain yang dilakukan mengisi waktu sehari hari.prevalensi aktvitas fisik kurang pada penduduk $\geq 10$ tahun berdasarkan data riseksdas didapatkan mengalami kenaikan dari tahun 2013 dan 2018 yaitu dari $26.1 \%$ menjadi 33.5\%. (Kemenkes, 2018).

Aktivitas fisik pada usia remaja sangat di anjurkan, beberapa manfaat aktivitas fisik pada usia remaja adalah meningkatkan pertumbuhan dan perkembangan sisten muskoloskeletal, mempertahankan dan mengontrol berat badan, membantu dalam perkembangan kehidupan social remaja, meningkatkan pengetahuan dan kecerdasan meningkatkan kreatifitas dan meningkatkan kemampuan dan ketrampilan tubuh . Salah satu aktivitas fisik atau latihan fisik yng terencana terprogram, benar, terukur dan teratur dapat meningkatkan kebugaran jasmani, program latihan fisik tersebut biasa disebut dengan olahraga.

Olahraga menurut (Giriwijoyo \& Sidik, 2013) terbagi menjadi empat macam yaitu olahraga prestasi, olahraga rekreasi, olahraga kesehatan dan olahraga pendidikan. Salah satu olahraga rekreasi adalah senam yang merupakan latihan tubuh yang dipilih dan diciptakan dengan berencana, disusun secara sistematis dengan tujuan membentuk dan mengembangkan pribadi secara harmonis (Margono, 2009). Tujuan dari senam adalah meningkatkan daya tahan tubuh, kekuatan, kelentukan, kelincahan, koordinasi serta kontrol tubuh (Mahendra, 2000) . Pemberian kegiatan senam harus memperhatikan kebutuhan siswa yakni harus sesuai kemampuan, minat dan potensi untuk mengembangkan kesanggupannya (Rahmawati \& Huda, 2018), salah satu senam yang mudah dan tidak memberatkan adalah senam penguin yang mulai terkenal dari tahun 2014.

Senam penguin merupakan salah satu jenis olahaga yang menarik. hal ini disebabkan karena gerakannya didominasi oleh gaya seperti pinguin seperti posisi tangan, langkah kaki dan gerakan berputar. Tempo gerakannya pun santai dan tidak menuntut banyak gerakan berat sehingga bisa dilakukan oleh siapa saja tanpa batasan usia. Untuk melakukan senam ini juga tidak perlu pemanasan yang terlalu lama dan bisa dilakukan dimana saja, kapan saja. Tujuan dari senam penguin nampaknya memang dibuat hanya sebagai hiburan semata. Tapi jangan salah senam ini bisa juga menjadi sebuah terapi untuk menenangkan pikiran, karena meskipun gerakannya santai tetapi hampir seluruh anggota badan dituntut untuk bergerak sehingga dapat meringankan stress dan membuat tubuh menjadi lebih segar).

Senam pinguin merupakan suatu gerakan yang tergolong unik, gerakannya didominasi oleh gaya pinguin mulai dari posisi tangan, langkah kaki, dan gerakan berputar. Senam pinguin tempo gerakannya pelan (Akibanation, 2016). Dalam sebuah penelitian mengai implementasi senam pagi mendapatkan dampak yang positif yaitu siswa merasa senang dengan kegiatan tersebut, terdapat peningkatan prestasi serta kebugaran dan kesehatan tubuh lebih baik (Rahmawati \& Huda, 2018).

\section{METODE}

Metode pangabdian masyarakat ini adalah dengan pendekatan metode demonstrasi atau mempraktekan olahraga bentuk senam penguin dengan menggunakan audiovisual youtube oleh instruktur dan diikuti oleh peserta dan diampingi oleh mahasiswa.sasaran dari 
pengabdian masyarakat ini adalah santri pondok pesantren Sabilunnajat yang mondok. Kegiatan pengabdian masyarakat ini dilaksanakan oleh Fakultas Kesehatan Masyarakat Universitas Muhammadiyah Jakarta yang bermitra dengan Pondok Pesantren Sabilunnajat Ciamis Jawa barat.

\section{HASIL DAN PEMBAHASAN}

Kegiatan pengabdian masyarakat ini dilaksanakan pada pukul 07.00 WIB yang sebelumnya mereka mereka melakukan pemanasan, senam kesegaran jasmani baru disipkan senam penguin. dimana sudah koordinasi sebelumnya dengan pihak pondok pesantren bahawa akan dilakukan implementasi senam penguin pada saat siswa sedang tidak ada kegiatan kelas atau pada saat hari libur.
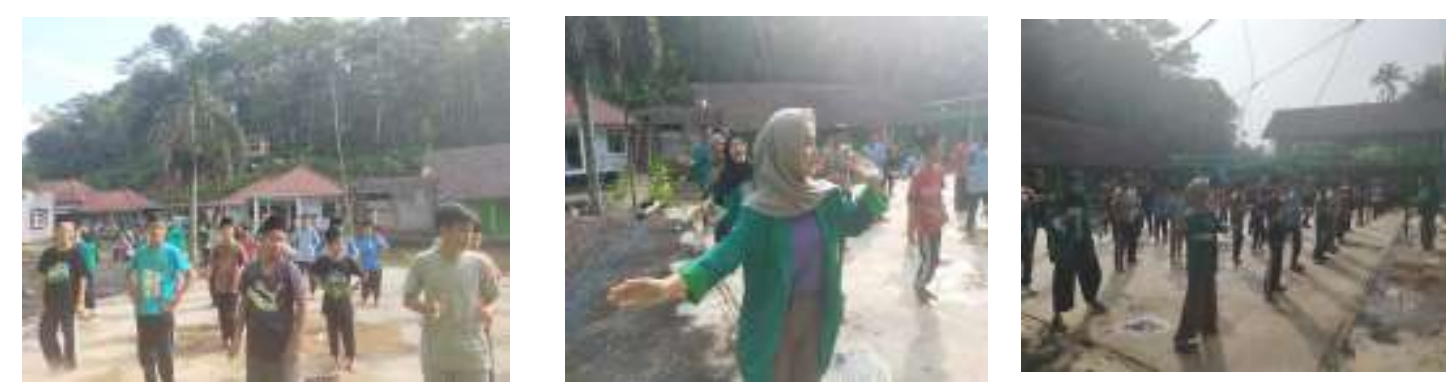

Sumber data primer 2020

Gambar 1 Pelaksanaan senam pinguin

Pada saat pelakasnaan pengabdian masyarakat sekitar 50 santri hadir dalam kegiatan senam. kegiatan pengabdian masyarakat ini dimulai dengan pemansan telebih dahulu yang dipimpin oleh salah satu santri. Selanjutnya setelah dilakukan pemanasan baru dilanjtkan senam kesegaran jasmani sekitar 15 menit yang, baru setelah itu diberikan senam penguin sekitar 3 menit. Setelah selesai melakukan senam beberapa santri di tanya bagaiamana perasaannya setelah diberikan senam penguin.

Semua santri diberikan kuesioner mengenai tanggapan hasil dari kegiatan senam penguin dengan jumlah pertanyaaan 5 dengan skor masing masing 2, jika skor diatas 6 maka senam penguin dirasakan bermanfaat namun jika skor dibawah 6 maka artinya kegiatan senam penguin dianggap kurang manfaat. Dari hasil rekapitulasi kuesioner sekitar 85 persen mempunyai skor diatas 6 , ini artinya bahwa santri merasakan senam penguin ini bermanfaat untuk kesehatan karena senam penguin ini dirasakan nyaman dan gerakan gerakannya tidak sulit serta tidak berat namun ada efek terhadap tubuh yaitu merasa relaks dan segar.

Bentuk senam penguin dikemas dalam beberapa bentuk gerakan yaitu :

1. Gerakan kepak sayap dengan menggerakan kedua tangan 30 derajat

2. Gerakan putar kepala, gerakan ini memutar kepala dan badan di codongkan ke depan, samping, kebelakang hingga ke empat arah

3. Gerak memutar badan, gerakan ini bergerak memutar seperti penguin dari kiri ke kanan

4. Gerakan tangan menggulung, gerakan tangan di lambaikan ke depan seperti menggulung benang

5. Gerakan kaki, gerakan ini kaki diangkat sedikit salah satu tangan menusuk kebawah.

Menurut (Ernam, 2018) senam penguin berfungsi untuk meningkatkan kebugaran jasmani faktor lain yang menjadikan semangat dalam senam selain gerakan adalah faktor musik juga, senam penguin mempunyai variasi gerakan yang variatif seperti penguin sehingga dengan 
variasi ini dapat membantu meningkatkan kesehatan dan kebugaran jasmani. Kegiatan diluar seperti senam dapat meningkatkan kesehatan jasmani dan rohani serta meningkatkan semangat kerja (Pujihartati, et al., 2019)

\section{KESIMPULAN DAN SARAN}

Dalam implementasi senam penguin pada santri memberikan dampak positif bagi santri yaitu timbulnya semangat untuk berolahraga sehingga kesehatan tubuh akan tetap terjaga. Diharapkan pelaksanaan ini bisa diterapkan pada santriwati dikarenakan pada saat pelaksanaan karena situasi dan kondisi tidak memungkinan maka santriwati tidak diikutkan dalam pelaksaan senam tersebut.

\section{UCAPAN TERIMA KASIH}

Kami mengucapkan terima kasih kepada seluruh pengurus Pondok Pesantren Sabilunnajat yang telah memberikan kami ruang untuk melakukan pengabdian masyarakat dalam bentuk implementasi olahraga. Dirasa perlu diterapkan di pondok pesantren . semoga bisa bermanfaat bagi umat umumnya dan pada santri khususnya.

\section{DAFTAR PUSTAKA}

Akibanation. 2016. menapak-tilas-fenomena-senam-pinguin-melejitkan-miku-mata-awam. [Online] Available at: https://www.akibanation.com/[Diakses 5 April 2020].

Ernam. 2018. senam-pinguin-membuat-peserta-tertawa-dan-sehat. [Online] Available at: https://pwmu.co/52429/02/02/senam-pinguin-membuat-peserta-tertawadan-sehat/[Diakses 20 April 2020].

Giriwijoyo, S. \& Sidik, D. Z. 2013. Ilmu Faal Olahraga (Fisiologi Olahraga): Fungsi Tubuh Manusia pada Olahraga untuk Kesehatan dan Prestasi.. Remaja Rosdakar.

Kemenkes. 2015. Pembinaan Kesehatan Olahraga Di Indonesia. Infodatin Pusat Data dan Informasi Kementerian Kesehatan RI.

Kemenkes. 2018. Hasil Utama Riskesdas 2018, Jakarta: Badan Penelitian dan Pengembangan Kesehatan.

Mahendra, A. 2000. Senam. Jakarta. Dirjen Dikdasmen Depdiknas.

Margono, A. 2009. Senam. Surakarta. UNS Press.

Miles, L. 2007. Physical Activity and Health.. s.l.:Nutr Bull.

Pujihartati, S. H., Wijaya, M. \& Gutama, T. A. 2019. Outbond Sebagai Sarana Meningkatkan

Kesehatan Jasmani dan Rohani di Perusahaan PT GarudaPrima Sentosa. Analisa Sosiologi. Volume 8 no. 2. pp. 83-94.

Rahmawati, A. \& Huda, A. 2018. Senam Pagi Membangun Motivasi Belajar Siswa Tunagrhita. ORTPEDAGOGIA. Juli.Volume 4. pp. 26-32. 